\title{
AFIKS-AFIKS DERIVASIONAL DAN TIPE-TIPE NOMINA DALAM KONSTRUKSI VERBA DENOMINATIF BAHASA INDONESIA
}

\author{
A. Danang Satria Nugraha
}

Program Studi Linguistik, Universitas Gadjah Mada

\begin{abstract}
This research aims to describe the linguistic features of the denominative verb construction (VDn) in bahasa Indonesia (bI). The construction of VDn is a verb derived from nouns, such as mengecat, menyekolahkan, berpakaian, bersepeda. This research utilizes observation in collecting the data and distributional method in analyzing the data. The Data sources are sentences on the use of bI either orally or in writing. This research shows that the VDn constructions, morphologically, are composed of derivational affixes and nouns. The derivational affixes are prefix, circumfix, simulfix, and a combination of affixes. The nouns are root noun, derived form, noun-phrase, animate noun, and inanimate noun.
\end{abstract}

Keywords: VDn constructions, derivational affixes, types of noun.

\begin{abstract}
Abstrak: Penelitian ini bertujuan mendeskripsikan ciri-ciri konstruksi verba denominatif (VDn) bahasa Indonesia (bI). Konstruksi VDn merupakan verba yang diderivasikan dari nomina, seperti mengecat, menyekolahkan, berpakaian, bersepeda, dan sejenisnya. Penelitian ini memanfaatkan metode observasi (simak) dalam penyediaan data dan metode distribusi (agih) dalam analisis data. Data berwujud kalimat yang bersumber pada penggunaan bI baik secara lisan maupun tertulis. Penelitian ini menunjukan konstruksi VDn bI secara morfologis terbentuk dari distribusi antara afiks derivasional dan nomina. Afiks derivasional berwujud prefiks, konfiks, simulfiks, dan kombinasi afiks. Nomina berwujud nomina dasar, nomina turunan, frasa nomina, nomina otentik, nomina ganda, nomina bernyawa, dan nomina tidak bernyawa.
\end{abstract}

Kata Kunci: konstruksi VDn, afiks derivasional, tipe nomina.

Verbalisasi merupakan fenomena linguistis yang lazim terjadi pada berbagai bahasa. Pada bahasa Inggris, nomina water, pocket, skin, dan google dapat diderivasikan menjadi verba, seperti pada klausa water the lawn 'mengairi halaman rumput', pocket the money 'mengantongi uang', skin the fruit 'menguliti buah', dan Tom is googling now 'Tom bermain google' (Rose, 1973:509; Kilgarriff, 2008:282; Aquaviva, 541; lihat pula Folli, 2013). Pada bahasa Tagalog, nomina doktor dan ulan dapat diderivasikan menjadi pagdoktor dan umu?lan, seperti pada klausa magdoktor ang anak ni Mang Ado 'anak Mang Ado akan menjadi seorang dokter' dan klausa umu?lan 'ini sedang hujan' (de Guzman, 1978:273). 
Pada bahasa Indonesia, verbalisasi nomina cenderung digunakan secara produktif. Meskipun pada tataran konvensional, nomina cenderung mengisi fungsi sintaktis subjek dan objek (Wijana, 1991b:1), nomina yang diverbalisasi dapat mengisi fungsi predikat pada konstruksi kalimat. Pada penelitian sebelumnya, Rose (1969; 1973; 1977a; 1977b), Ramlan (1978), Sumarmo (1977), Suhandano (1990; 1991), dan Wijana (1991a) mencatat konstruksi VDn yang dimarkahi afiks $\{\mathrm{me}(\mathrm{N})-\mathrm{i}\}$, misalnya, merupakan konstruksi produktif yang digunakan sebagai predikat, misalnya mengairi, menggambari, mendindingi, menyisiki, dan membului. Sementara itu, Nanyang Technological University Multilingual Corpus (2015), misalnya, merilis persentase penggunaan konstruksi merupakan sebesar 26,4\% atau 125 dari 473 kali penggunaan. Pengukuran itu dilakukan dalam perbandingan dengan penggunaan verba yang lain seperti adalah, ialah, dan menjadi.

Konstruksi verba denominatif (VDn), lebih lanjut, merupakan konstruksi gramatikal. Setiap konstruksi gramatikal terdiri atas perpaduan antara bentuk morfologis, jaringan fungsi sintaktis, dan makna semantis (Suhandano, 2002; Dixon, 2008; Dixon, 2010; Wijana, 2010). Bentuk morfologis mengacu pada formatif atau wujud fisik dari VDn yang dapat menjadi konstituen dari konstruksi gramatikal pada tataran yang lebih kompleks (Katamba, 1993). Makna semantis mengacu pada proposisi atau substansi makna yang direpresentasikan oleh VDn (Chafe, 1970). Sebagai contoh, cermatilah nomina laut yang muncul dalam konstruksi melaut sebagai konstituen gramatikal dari kalimat (1). Konstruksi lain seperti melauti, melautkan, ?berlaut, ?berlautkan, ?terlaut, atau ?terlautkan, meskipun sama-sama diwujudkan dari nomina laut, secara sintaktis dan semantis tidak gramatikal apabila diposisikan sebagai konstituen pengisi fungsi predikat kalimat nomor (1).

(1) Nelayan itu melaut ketika matahari mulai terbenam.

(1a) *Nelayan itu melauti ketika matahari mulai terbenam.

(1b) * Nelayan itu melautkan ketika matahari mulai terbenam.

Kekhasan konstruksi VDn seperti dicontohkan pada kalimat (1) berkaitan dengan sifat kesentralan verba dalam bahasa. Verba itu sentral dalam bahasa, sentral dalam arti verbalah yang pertama-tama menentukan adanya berbagai struktur dari konstruksi beserta dengan perubahannya (Sudaryanto, 1983:6; Kaswanti-Purwo, 1989; Poedjosoedarmo, 2001; im Walde, 2004). Dalam konstruksi VDn, perubahan itu berwujud penyesuaian gramatikal yang khusus seperti (a) tidak semua nomina dapat diderivasikan ke dalam konstruksi VDn dan (b) tidak semua afiks dapat menderivasikan nomina ke dalam konstruksi VDn. Dalam penelitian ini, perubahan-perubahan tersebut dicoba dilacak dengan kerangka penelitian morfologis. Untuk itu, pada bagian selanjutnya dibicarakan secara berurutan (a) afiks-afiks derivasional dan (b) tipe-tipe nomina yang dapat diderivasikan.

\section{METODE}

Penelitian ini dilakukan dalam tiga tahapan, yaitu pengumpulan data, penganalisisan data, dan penyajian hasil analisis. Pertama, pengumpulan data. Data dalam penelitian ini berwujud kalimat deklaratif yang berpredikat VDn. Kalimat bersumber pada penggunaan bI baik secara lisan maupun tertulis. Pengumpulan data dilakukan dengan metode observasi (simak). Kedua, penganalisisan data. Unit analisis adalah konstruksi VDn yang mengisi fungsi predikat. Penganalisisan dilakukan dengan menggunakan metode agih atau distribusional. Dalam analisis tersebut, afiks-afiks derivasional dan nomina-nomina 
diidentifikasikan dan diklasifikasikan sesuai kategorinya. Identifikasi dan klasifikasi diwujudkan dalam matriks analisis. Sebagai contoh, periksalah matriks 1.

\section{Matriks 1 Prefiks Derivasional dan Formatif Dasar}

\begin{tabular}{llll}
\hline \multicolumn{2}{l}{ Prefiks dan Dasar dalam Konstruksi VDn } & \\
Prefiks & Dasar & VDn & Kalimat \\
\hline$\{$ me(N)- $\}$ & Sapu & Menyapu & Nenek menyapu halaman. \\
$\{$ ber- $\}$ & Kemeja & Berkemeja & Saya berkemeja untuk acara itu. \\
$\{$ ter- $\}$ & Panah & Terpanah & Elang ini terpanah di ngarai. \\
$\{$ di- $\}$ & Sendok & Disendok & Kuahnya disendok ibu. \\
\hline
\end{tabular}

Ketiga, penyajian hasil analisis. Penyajian hasil analisis dilakukan dengan menggunakan metode informal dan formal. Melalui metode informal, hasil analisis disajikan dalam kalimat-kalimat penjelasan. Sementara itu, melalui metode formal, kaidah-kaidah linguistis tentang proses derivasi nomina disajikan dalam bagan-bagan seperti disajikan pada bagan 1 .

\section{HASIL}

Konstruksi verba denominatif (VDn) dalam bahasa Indonesia dapat terbentuk melalui proses penambahan afiks. Proses tersebut mensyaratkan dua unsur utama, yakni morfem afiks dan morfem dasar. Pertama, morfem afiks. Morfem afiks dalam proses tersebut merupakan anggota kelas afiks derivasional. Afiks derivasional memiliki status sebagai penentu pembentukan konstruksi derivatif (Katamba, 1993; Booij, 2006). Sementara itu, morfem dasar yang diderivasikan adalah nomina. Nomina merupakan kelas kata yang secara semantis sering berpadanan dengan orang, benda, atau hal lain yang dibendakan dalam alam luar bahasa dan yang secara sintaktis biasanya dapat mengisi fungsi subjek dan objek (Kridalaksana, 2009:163). Dalam realisasinya, konstruksi-konstruksi VDn memiliki ciri morfologis yang berbeda dari wujud dasarnya (Akmajian, Demers, dan Harnish, 1979:117; McCune, 1985).

Afiks-afiks derivasional dalam konstruksi VDn sekurang-kurangnya terdiri atas empat jenis, yaitu prefiks, konfiks, simulfiks, dan kombinasi afiks. Wujud dari tiap-tiap afiks tersebut dapat disimak pada matriks 2 berikut.

\section{Matriks 2 Afiks-afiks Derivasional dalam Konstruksi VDn Bahasa Indonesia}

\begin{tabular}{ll}
\hline Afiks-afiks Derivasional \\
\hline Prefiks & $\{$ me $(\mathrm{N})-\},\{$ ber- $\},\{$ ter- $\},\{$ di- $\}$ \\
Konfiks & $\{$ ber-an $\},\{$ ber-R-an $\},\{$ ber-kan $\},\{$ ke-an $\}$, \\
Simulfiks & $\{\mathrm{N}-\}$ \\
& $\{$ me $(\mathrm{N})-\mathrm{i}\},\{$ di-i $\},\{$ me $(\mathrm{N})-\mathrm{kan}\},\{$ di-kan $\}$, \\
Kombinasi Afiks & $\{$ memper- $\},\{$ diper- $\},\{$ memper-kan $\}$, \\
& $\{$ diper-kan $\},\{$ memper-i $\},\{$ diper-i $\}$, \\
& $\{$ me $(\mathrm{N})-\mathrm{R}\},\{$ di-R $\},\{$ ber-R $\},\{\mathrm{N}-\mathrm{in}\}$ \\
\hline
\end{tabular}

Simaklah juga realisasi afiks-afiks tersebut di dalam konstruksi VDn pada kalimatkalimat (2) sampai (7) berikut. 
(2) Dan mulailah pemuda hitam itu membungkus pinggul dan kaki dengan kain batik pinjaman ibunya; serba terampil sulit dikoreksi kaum perempuan; wiru-wiru rapi agak di samping kiri. (Mangunwijaya, 1999)

(3) Setelah wig pinjaman memahkotai kepala dan kebaya merah semerawang dipakai, berubahlah karikatur pemuda berbeha itu menjadi Rara Ireng klasik betul yang luwes. (Mangunwijaya, 1999)

(4) Mas Kamin, abang sulungku, dulu disekolahkan di Muntilan, di Sekolah Misi, begitu namanya. (Mangunwijaya, 1999)

(5) Siang sungguh panas luar biasa. Burung-burung pun tiada yang berkicau. Setiap orang bernalar sehat pasti mencari bayangan sejuk. (Mangunwijaya, 1999)

(6) Kasirin sedang menggembala domba-dombanya. Tugas satu itulah, selain menyapu halaman, yang dapat dipercayakan oleh ayahnya kepada anak malas-entah-akan jadiapa. (Mangunwijaya, 1999)

(7) Dan mereka tiba-tiba melihat sebuah bangunan mungil berbingkai tembok-tembok bata merah dengan tiang-tiang penguat berukir yang bermahkotakan kuncup-kuncup besar berbentuk bunga teratai dari batu kapur putih. (Mangunwijaya, 1999)

Kedua, morfem dasar. Berdasarkan analisis data, dapat diketahui bahwa morfem dasar nomina pada konstruksi VDn memiliki tiga kecenderungan tipe. Tiga tipe tersebut adalah kelompok (a) nomina dasar, nomina turunan, dan frasa nomina, (b) nomina otentik dan nomina ganda, dan (c) nomina bernyawa dan nomina tidak bernyawa. Nomina dasar dimarkahi oleh tidak adanya afiks pada formatif dasar sebelum diderivasikan, misalnya bungkus, koreksi, mahkota, beha, sekolah, kicau, nalar, gembala, sapu, percaya, bingkai, dan bentuk. Nomina turunan ditandai oleh adanya afiks pada formatif dasar sebelum diderivasikan, seperti pakaian, kesempatan, dan kepribadian. Frasa nomina dapat berwujud daya juang dan meja hijau. Nomina otentik dimarkahi oleh adanya status definitif dari morfem dasar sebagai nomina, seperti mahkota, sapu, dan gembala. Nomina ganda dimarkahi oleh status ganda dari morfem dasar sebagai nomina atau verba, seperti pandang, kerlip, rajam, dan kedip. Nomina bernyawa dimarkahi oleh kehadiran referen makna dengan fitur semantis [+bernyawa, +beraktivitas], misalnya gembala. Nomina tidak bernyawa dimarkahi oleh kehadiran referen makna dengan fitur semantis [-bernyawa, -beraktivitas], misalnya bungkus, koreksi, sekolah, kicau, nalar, percaya, dan bentuk.

\section{PEMBAHASAN}

Secara morfologis, kata-kata derivasional yang berasal dari suatu morfem dasar memiliki pola yang dapat diruntut dan kaidah-kaidah derivasinya dapat dikatakan sebagai 'kaidah beruntun' (Verhaar, 1996:144). Dalam konstruksi VDn, pelacakan pola dan kaidah dapat diawali dengan memarkahi afiks (Verhaar, 1984a; Wijana, 2016), sebelum memarkahi tipe morfem-morfem dasar nomina. Secara lengkap, pembahasan afiks-afiks derivasional dan tipe-tipe nomina disajikan sebagai berikut.

\section{Afiks-afiks Derivasional}

Pembentukan verba bahasa Indonesia dapat diproses melalui derivasi dengan memanfaatkan afiks. Dalam proses tersebut, afiksasi mengubah kategori atau identitas leksikal suatu kata, misalnya dari nomina menjadi verba. Afiks dengan ciri linguistis seperti itu diklasifikasikan sebagi afiks derivasional (Kridalaksana, 2009:3; Bussmann, 1996; 
Dreyfuss, 1978, Booij, 2013:654-655). They change the word class of the base (Moravcsik, 2013:143). Dalam konstruksi VDn, afiks derivasional sekurang-kurangnya dapat dikelompokan ke dalam empat jenis, yaitu prefiks, konfiks, simul-fiks, dan kombinasi afiks. Tiap-tiap kelompok tersebut secara lengkap dideskripsikan dalam bagian-bagian berikut.

\section{Prefiks}

Konstruksi VDn yang dibentuk melalui penambahan prefiks merupakan proses yang lazim terjadi. Derivational morphology by prefixation is common (Brown, 2006:163). Dalam proses tersebut, distribusi antara prefiks dan nomina membentuk kata-kata derivasional dengan pola yang ajeg dan makna baru yang utuh (Chaer, 2012). The components must appear together, in fixed order, with the word having conventionalised coherence and meaning (Dixon dan Aikhenvald, 2002:36). Berdasarkan hasil penelitian, sekurangkurangnya terdapat empat prefiks yang dapat menderivasikan nomina menjadi VDn, yaitu $\{$ me $(\mathrm{N})-\},\{$ ber- $\},\{$ ter- $\}$, dan $\{$ di- $\}$ seperti dalam contoh membatik, berpidato, terpanah, dan ditali pada kalimat (8) sampai (11).

\section{Bagan 1 Kaidah Distribusi Prefiks Pembentuk VDn}

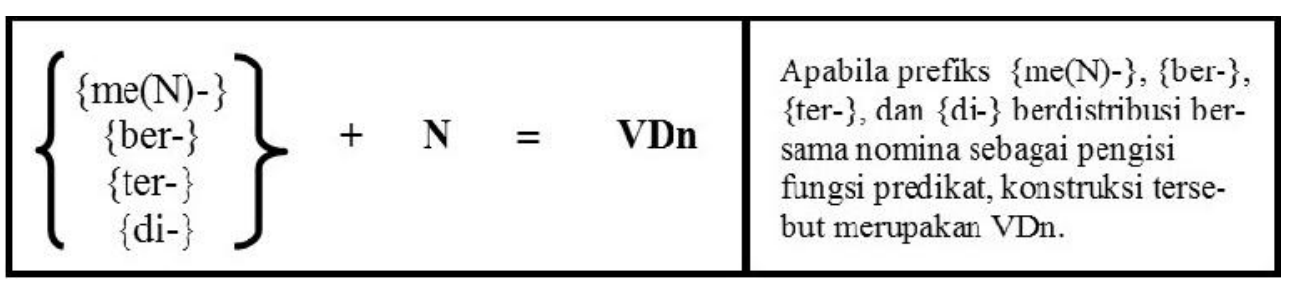

Periksalah contoh (8) sampai (11) berikut.

(8) Damarhadi membatik kain sutera sejak menerima pesanan dari Dalem Ageng Kraton.

(9) Presiden berpidato di istana Bogor.

(10) Burung itu terpanah ketika bertengger di dahan pepohonan.

(11) Gulungan karpet itu biasa ditali oleh bujang seusai pengajian.

Pada kalimat (8) sampai (11), berturut-turut, konstruksi membatik diderivasikan dari batik melalui penambahan prefiks $\{\mathrm{me}(\mathrm{N})-\}$, konstruksi berpidato diderivasikan dari pidato melalui penambahan prefiks \{ber-\}, konstruksi terpanah diderivasikan dari panah melalui penambahan afiks \{ter-\}, dan konstruksi ditali diderivasikan dari tali melalui penambahan afiks $\{$ di- $\}$. Verhaar (1978) menyebutkan prefiks $\{$ di- $\}$ sebagai pembentuk pasif perimbangan dari prefiks aktif $\{\mathrm{me}(\mathrm{N})-\}$ Kata-kata tersebut merupakan realisasi dari leksem BATIK, PIDATO, PANAH, dan TALI.

\section{Konfiks}

Selain melalui penambahan afiks, konstruksi VDn dapat dibentuk melalui penambahan konfiks pada nomina. Konfiks yang disebut juga dengan sirkumfiks dibatasi pengertiannya sebagai afiks tunggal yang terjadi dari dua bagian yang terpisah (Kridalaksana, 2009:130, 223; Crystal, 2008:16). Berdasarkan hasil penelitian, sekurang-kurangnya terdapat empat konfiks yang dapat menderivasikan nomina menjadi VDn, yaitu $\{$ ber-an $\}$, \{ber-R-an $\}$, \{ber- 
kan\}, dan \{ke-an\} seperti dalam contoh berkedipan, bersalam-salaman, bercitarasakan, dan kemalaman.

\section{Bagan 2 Kaidah Distribusi Konfiks Pembentuk VDn}

\begin{tabular}{|c|c|c|c|c|c|}
\hline $\begin{array}{c}\{\text { ber-an\} } \\
\text { ber-R-an\} } \\
\{\text { ber-kan }\} \\
\{\text { ke-an }\}\end{array}$ & + & $\mathbf{N}$ & $=$ & VDn & $\begin{array}{l}\text { Apabila konfiks \{bcr-an\}, \{bcr-R } \\
\text {-an\}, \{ber-kan\}, dan \{ke-an\} ber- } \\
\text { distribusi bersama nomina sebagai } \\
\text { pengisi fungsi predikat, konstruksi } \\
\text { tersebut mlerupakan VDı. }\end{array}$ \\
\hline
\end{tabular}

Periksalah contoh (12) sampai (15) berikut.

(12) Matanya berkedipan ketika lampu tiba-tiba mati.

(13) Para duta besar bersalam-salaman sebelum memulai pertemuan.

(14) Masakan ini bercitarasakan kaldu tradisional Jawa.

(15) Dia kemalaman ketika acara penting itu dilaksanakan.

Pada kalimat (12) sampai (15), berturut-turut, konstruksi berkedipan diderivasikan dari kedip melalui penambahan afiks \{ber-an\}, konstruksi bersalam-salaman diderivasikan dari salam melalui penambahan afiks \{ber-R-an\}, konstruksi bercitarasakan diderivasikan dari citarasa melalui penambahan konfiks \{ber-kan\}, dan konstruksi kemalaman diderivasikan dari malam melalui penambahan afiks $\{k e-a n\}$. Kata-kata tersebut merupakan realisasi dari leksem KEDIP, SALAM,CITARASA, dan MALAM.

\section{Simulfiks}

Konstruksi verba denominatif dapat dibentuk melalui penambahan simulfiks pada nomina. Simulfiks dibatasi pengertiannya sebagai afiks yang tidak berbentuk suku kata dan yang ditambahkan atau dileburkan pada morfem dasar (Kridalaksana, 2009:222). Berdasarkan hasil penelitian, sekurang-kurangnya terdapat satu simulfiks yang dapat menderivasikan nomina menjadi VDn, yakni $\{\mathrm{N}-\}$ seperti dalam ngampus dan mbakso.

\section{Bagan 3 Kaidah Distribusi Simulfiks Pembentuk VDn}

\begin{tabular}{|l|l|}
\hline$\{\mathbf{N}\}+\mathbf{N}=\mathbf{V D n}$ & $\begin{array}{l}\text { Apabila konfiks }\{\mathrm{N}-\} \text { berdistribusi } \\
\text { bersama nomina sebagai pengisi } \\
\text { fungsi predikat, konstruksi terse- } \\
\text { but merupakan VDn. }\end{array}$ \\
\hline
\end{tabular}

Periksalah contoh (16) sampai (17) berikut.

(16) Mereka ngampus hanya karena takut pada dosennya.

(17) Kami mbakso setiap hari sabtu malam.

Pada kalimat (16) dan (17), konstruksi ngampus diderivasikan dari kampus dan mbakso diderivasikan dari bakso melalui penambahan simulfiks $\{\mathrm{N}-\}$. Kedua kata tersebut merupakan realisasi dari leksem KAMPUS dan BAKSO. 


\section{Kombinasi Afiks}

Konstruksi verba denominatif dapat dibentuk melalui penambahan kombinasi afiks pada nomina. Kombinasi afiks dibatasi pengertiannya sebagai penggabungan dua afiks atau lebih yang dapat berdistribusi dengan dasar (Kridalaksana, 2009:31). Lebih lanjut, Kridalaksana (2009) menambahkan kombinasi afiks bukan jenis afiks khusus dan hanya merupakan gabungan beberapa afiks yang mempunyai bentuk dan makna gramatikal tersendiri, muncul secara bersama pada bentuk dasar. Berdasarkan hasil penelitian, sekurang-kurangnya terdapat empat belas kombinasi afiks yang dapat menderivasikan nomina menjadi VDn, yaitu $\{\operatorname{me}(\mathrm{N})-\mathrm{i}\},\{$ di-i $\},\{\operatorname{me}(\mathrm{N})-\mathrm{kan}\},\{$ di-kan $\},\{$ memper- $\},\{$ diper- $\},\{$ memper-kan $\}$, \{diperkan $\},\{$ memper-i $\},\{$ diper-i $\},\{$ me $(N)-R\},\{$ di-R $\},\{$ ber-R $\}$, dan $\{N-i n\}$. Simaklah kalimat (18) sampai (24) berikut.

(18) Made memahati batu itu sejak setahun lalu.

(19) Sepatu ini disikati adik setiap pagi.

(20) Ibu menyekolahkan anak-anaknya di satu lembaga sekolah yang sama.

(21) Gincu mempermerah bibirnya yang mungil itu.

(22) Rakyat diperbudak raja selama satu windu.

(23) Nelson tidak memperbedakan hal-hal elementer seperti warna kulit.

(24) Gadjah Mada diperhambakan oleh Hayam Wuruk.

Pada kalimat (18) sampai (24), berturut-turut, konstruksi memahati diderivasikan dari pahat melalui penambahan afiks $\{\mathrm{me}(\mathrm{N})-\mathrm{i}\}$, konstruksi disikati diderivasikan dari sikat melalui penambahan afiks $\{\mathrm{di}-\mathrm{i}\}$, konstruksi menyekolahkan diderivasikan dari sekolah melalui penambahan afiks $\{\mathrm{me}(\mathrm{N})-\mathrm{kan}\}$, konstruksi mempermerah diderivasikan dari merah melalui penambahan afiks \{memper-\}, konstruksi diperbudak diderivasikan dari budak melalui penambahan afiks \{diper-\}, konstruksi memperbedakan diderivasikan dari beda melalui penambahan afiks \{memper-kan\}, dan konstruksi diperhambakan diderivasikan dari hamba melalui penambahan afiks \{diper-kan\}. Kata-kata tersebut merupakan realisasi dari leksem PAHAT, SIKAT, SEKOLAH, MERAH, BUDAK, BEDA, dan HAMBA.

\section{Bagan 4 Kaidah Distribusi Kombinasi Alfiks Pembentuk VDn}

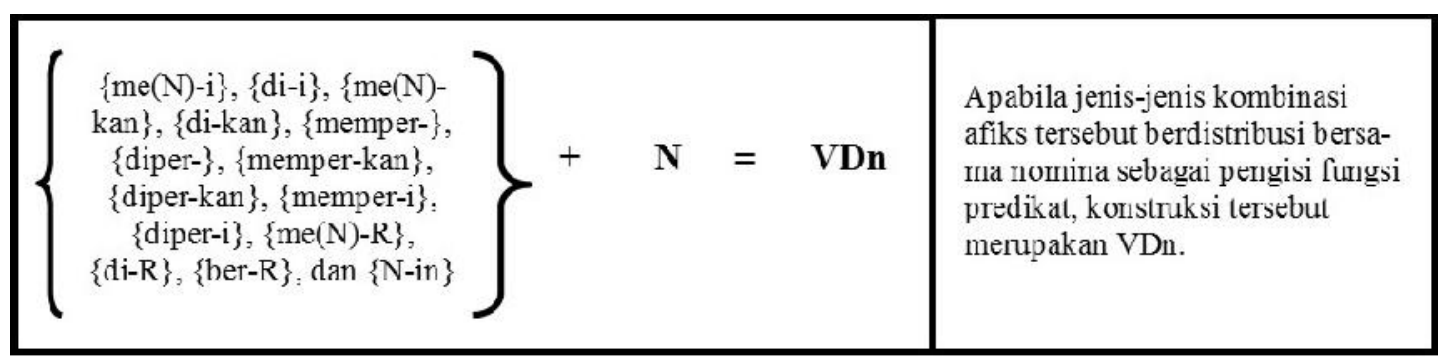


Selanjutnya, simaklah kalimat (25) sampai (31) berikut.

(25) Bi Ijah ngegaramin sayur lodeh.

(26) Anjing itu mencakar-cakar pintu rumah.

(27) Habis sudah majalah ini digunting-gunting oleh adikmu.

(28) Mereka berbisik-bisik selama mengikuti presentasi direktur.

(29) Sembilan tahun lalu, saya diasramakan ke seminari.

(30) Duri-duri mempercederai para pelari maraton.

(31) Kami telah dipersenjatai dengan alat-alat terbaru untuk penjagaan ZEE di laut utara Maluku

Pada kalimat (25) sampai (31), berturut-turut, konstruksi ngegaramin diderivasikan dari garam melalui penambahan afiks $\{\mathrm{N}$-in $\}$, konstruksi mencakar-cakar diderivasikan dari cakar melalui penambahan afiks $\{\mathrm{me}(\mathrm{N})-\mathrm{R}\}$, konstruksi digunting-gunting diderivasikan dari gunting melalui penambahan afiks $\{$ di-R $\}$, konstruksi berbisik-bisik diderivasikan dari bisik melalui penambahan afiks \{berR\}, konstruksi diasramakan diderivasikan dari asrama melalui penambahan afiks \{di-kan\}, konstruksi mempercederai diderivasikan dari cedera melalui penambahan afiks \{memper-i\}, dan konstruksi dipersenjatai diderivasikan dari senjata melalui penambahan afiks \{diper-i\}. Kata-kata tersebut merupakan realisasi dari leksem GARAM, CAKAR, GUNTING, BISIK, ASRAMA, CEDERA, dan SENJATA.

\section{Tipe-tipe Nomina}

Salah satu unsur utama dalam konstruksi VDn adalah nomina. Nomina dibatasi pengertiannya sebagai a term used in the grammatical classification of words, traditionally defined as the 'name of a person, place or thing', but the vagueness associated with the notions of 'name' and 'thing' (Crystal, 2008:332). Nomina yang diderivasikan menjadi VDn dapat berwujud (a) nomina dasar, turunan, dan frasa nomina, (b) nomina otentik dan ganda, dan (c) nomina bernyawa dan tidak bernyawa. Nomina dasar berwujud morfem bebas (Sneddon, dkk. 1996). Nomina turunan berwujud morfem bentukan sebelum diderivasikan (Aikenvald dan Dixon, 2007). Frasa nomina berwujud nomina yang berdistribusi dalam konstruksi frasa (Dixon dan Aikenvald, 2002). Nomina otentik merupakan nomina yang status kenominaannya pasti/definitif dan tidak relatif. Nomina ganda yang disebut juga nomina polar merupakan nomina yang status kenominaannya masih relatif; pada satu konstruksi dapat berupa nomina dan pada konstruksi lainya dapat berupa verba atau kelas kata yang lainnya. Nomina bernyawa mengacu pada referen-referen yang memiliki fitur semantis nyawa atau hidup dan beraktivitas. Nomina tidak bernyawa mengacu pada referenreferen yang tidak memiliki nyawa atau mati dan tidak beraktivitas. Secara lengkap, tipe-tipe nomina tersebut dibahas pada bagian berikut.

\section{Nomina Dasar, Nomina Turunan, dan Frasa Nomina}

Nomina dasar, nomina turunan, dan frasa nomina merupakan tipe-tipe nomina yang dapat diderivasikan menjadi VDn. Pertama, nomina dasar. Nomina dasar (ND) seperti pasak, tali, sapu, buku, drama, dan film dapat diderivasikan menjadi verba. Nomina dasar dimarkahi oleh hanya terdiri atas satu morfem (Parker dan Riley, 2014). A word consisting of a single (free) morpheme is a monomer-phemic word (Crystal, 2008:313). Kedua, nomina turunan. Nomina turunan (NT) seperti pakaian, kesempatan, dan kepribadian dapat diderivasikan 
menjadi verba. Nomina turunan dikenal juga dengan istilah polimorfemis; $a$ word consisting of two or more than two morpheme is a polymorphemic word (Crystal, 2008:313). Ketiga, frasa nomina (Verhaar, 1988a; Verhaar, 1988b). Nomina dalam wujud frasa (FN) seperti daya juang, cita rasa, meja hijau, dan rumah sakit dapat diderivasikan menjadi verba.

\section{Bagan 5 Kaidah Distribusi ND, NT, dan FN}

\begin{tabular}{|c|c|c|c|}
\hline $\begin{array}{c}\text { Afiks } \\
\text { Derivasional }\end{array}$ & $+\left\{\begin{array}{l}\text { ND } \\
\text { NT } \\
\text { FN }\end{array}\right\}$ & $=\quad$ VDn & $\begin{array}{l}\text { Apabila berdistribusi dengan afiks } \\
\text { derivasional, ND, NT, dan FN } \\
\text { membentuk konstruksi VDn yang } \\
\text { merngisi furngsi predik al. }\end{array}$ \\
\hline
\end{tabular}

Simaklah contoh (31) sampai (33) berikut.

(31) Petugas PU menyapu kawasan jalan Soekarno-Hatta.

(32) Para delegasi berpakaian adat sesuai asal mereka.

(33) Masakan ini bercita rasa rempah-rempah khas Padang.

Pada contoh (31) sampai (33), berturut-turut didapati contoh menyapu, berpakaian, dan bercita rasa. Nomina sapu merupakan nomina dasar dengan tanda dapat dinegasikan menjadi bukan sapu dan diberi atribusi menjadi sapu baru. Nomina pakaian merupakan nomina turunan dengan tanda dapat dilakukan pemilahan antara morfem $\{-a n\}$ dan morfem \{pakai yang membentuk pakaian. Karena merupakan nomina kompleks, wujud pakai tidak dapat digunakan pada konstruksi VDn. Wujud * berpakai merupakan wujud yang tidak gramatikal. Status verba pada bercita rasa dapat diuji dengan menambahkan negasi tidak, misalnya tidak bercita rasa, status bercita rasa sebagai verba.

\section{Nomina Otentik dan Nomina Ganda}

Nomina otentik (NO) dan nomina ganda (NG) merupakan tipe-tipe nomina yang dapat diderivasikan menjadi verba denominatif. Pembedaan antara kedua tipe nomina tersebut merupakan alternatif untuk mewadahi adanya kecenderungan ketidakpastian status kenominaan pada konstruksi-konstruksi atau formatif dasar dalam bahasa Indonesia (Verhaar, 1984b). Pertama, nomina otentik. Nomina otentik merupakan nomina yang status kenominaannya sudah pasti dan tidak bias. Tidak bias maksudnya tidak dapat diperdebatkan lagi apakah suatu formatif berkelas nomina atau berkelas lainnya. Simaklah konstruksi seperti memayungi, memagari, mengecat, bercermin, dan bersepeda. Kedua, nomina ganda. Nomina ganda merupakan nomina yang status kenominaannya belum pasti dan bias. Bias maksudnya dapat diperdebatkan lagi apakah suatu formatif berkelas nomina atau berkelas lainnya. Simaklah konstruksi seperti berkedipan, berkerlipan, dan merajut.

\section{Bagan 6 Kaidah Distribusi NO dan NG}

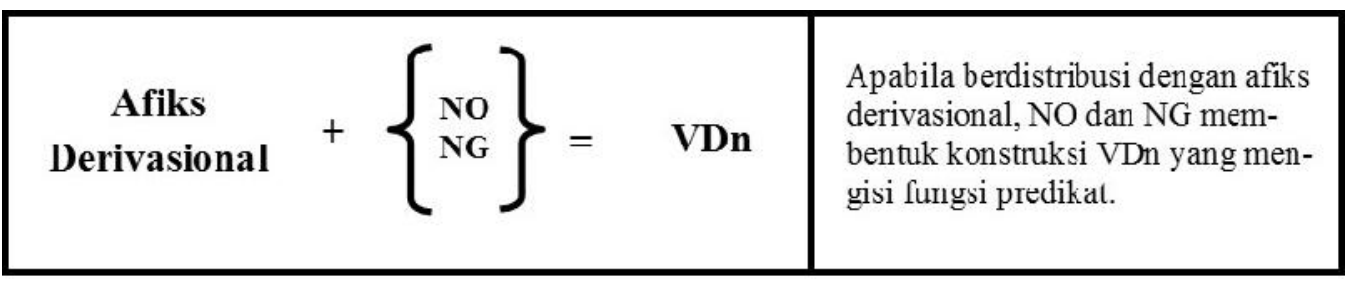


Periksalah contoh (34), dan (35) berikut.

(34) Elsandika memayungi mama saat hujan siang itu.

(35) Bintang-bintang berkerlipan malam ini.

Konstruksi memayungi diderivasikan dari payung melalui penambahan afiks $\{\operatorname{me}(\mathrm{N})-\mathrm{i}\}$. Kedua kata tersebut merupakan realisasi dari leksem PAYUNG. Status verba pada memayungi dapat diuji dengan menambahkan negasi tidak, misalnya tidak memayungi, status memayungi sebagai verba. Selain itu, dapat pula ditambahkan pernyataan kala absolut, seperti akan memayungi dan sedang memayungi. Sementara itu, konstruksi berkerlipan diderivasikan dari kerlip melalui penambahan afiks \{ber-an\}. Kedua kata tersebut merupakan realisasi dari leksem KERLIP. Status verba pada berkerlipan dapat diuji dengan menambahkan negasi tidak, misalnya tidak berkerlipan, status berkerlipan sebagai verba. Selain itu, dapat pula ditambahkan pernyataan kala absolut, seperti akan berkerlipan dan sedang berkerlipan.

\section{Nomina Bernyawa dan Nomina Tidak Bernyawa}

Nomina bernyawa dan nomina tidak bernyama merupakan tipe-tipe nomina yang dapat diderivasikan menjadi verba denominatif. Pertama, nomina bernyawa. Nomina bernyawa (NB) seperti ular, semut, nenek, kakek, paman dan bibi dapat diderivasikan menjadi verba. Nomina bernyawa dibatasi pengertiannya sebagai nomina yang mengacu pada referenreferen yang memiliki nyawa atau hidup. Nomina ini terdiri atas enam subkelas. Simaklah matriks 2 yang menyajikan informasi tentang subkelas nomina bernyawa.

\section{Matriks 2 Subkelas Nomina Bernyawa}

\begin{tabular}{|c|c|c|c|}
\hline & \multicolumn{3}{|l|}{ Nomina Bernyawa (NB) } \\
\hline & Subkelas & Contoh & Contoh VDn \\
\hline 1. & Nama diri (NDi) & Jokowi, Ahok & $\begin{array}{l}\text { menjokowikan, } \\
\text { mengahokkan }\end{array}$ \\
\hline 2. & $\begin{array}{l}\text { Nomina kekerabatan } \\
(\mathrm{NK})\end{array}$ & $\begin{array}{l}\text { Kakek, nenek, } \\
\text { paman, bibi }\end{array}$ & $\begin{array}{l}\text { berkakek, bernenek, } \\
\text { berabang, berpaman, berbibi }\end{array}$ \\
\hline 3. & $\begin{array}{l}\text { Nomina yang } \\
\text { menyatakan orang atau } \\
\text { diperlakukan seperti } \\
\text { orang (NO) }\end{array}$ & $\begin{array}{l}\text { tuan, hantu, raksasa, } \\
\text { nyonya }\end{array}$ & $\begin{array}{l}\text { menyonyakan, bertuan, } \\
\text { menghantui, }\end{array}$ \\
\hline 4. & $\begin{array}{l}\text { Nama kelompok } \\
\text { manusia atau suku } \\
\text { bangsa (NS) }\end{array}$ & $\begin{array}{l}\text { Jawa, Cina, Bugis, } \\
\text { Arab }\end{array}$ & $\begin{array}{l}\text { menjawakan, mencinakan, } \\
\text { membugiskan, } \\
\text { mengarabkan }\end{array}$ \\
\hline 5. & Flora dan fauna $(\mathrm{FF})$ & $\begin{array}{l}\text { ular, semut, kuda, } \\
\text { anjing }\end{array}$ & $\begin{array}{l}\text { berkuda, mengular, } \\
\text { menyemut, menganjingkan }\end{array}$ \\
\hline 6. & $\begin{array}{l}\text { Nama organ fisik } \\
\text { makhluk hidup (OF) }\end{array}$ & $\begin{array}{l}\text { mata, rambut, ekor, } \\
\text { kulit }\end{array}$ & $\begin{array}{l}\text { bermata, berambut, } \\
\text { menguliti. }\end{array}$ \\
\hline
\end{tabular}

Kedua, nomina tidak bernyawa. Nomina tidak bernyawa (NTB) seperti seperti jawa, sepatu, laut, dan kemeja dapat diderivasikan menjadi verba. Nomina tidak bernyawa dibatasi pengertiannya sebagai nomina yang mengacu pada referen-referen yang tidak memiliki 
nyawa atau mati. Nomina ini terdiri atas sebelas subkelas. Simaklah matriks 3 yang menyajikan informasi tentang subkelas nomina bernyawa.

\section{Matriks 3 Subkelas Nomina Tidak Bernyawa}

\begin{tabular}{|c|c|c|c|}
\hline & \multicolumn{3}{|c|}{ Nomina Tidak Bernyawa (NTB) } \\
\hline & Subkelas & Contoh $\mathbf{N}$ & Contoh VDn \\
\hline 1. & Nama geografis (NG) & $\begin{array}{l}\text { Bali, Papua, Malaysia Sumatera, } \\
\text { Indonesia, } \\
\text { Singapura, gunung, bukit, sungai, } \\
\text { ngarai, laut }\end{array}$ & $\begin{array}{l}\text { diindonesiakan, } \\
\text { dimalaysiakan, } \\
\text { disingapurakan }\end{array}$ \\
\hline 2. & Nama lembaga (NL) & KPK, polisi, MK, MA & di-KPK-kan, dipolisikan \\
\hline 3. & Nomina waktu (NW) & $\begin{array}{l}\text { akhir pekan, awal bulan, bulan, } \\
\text { tahun, windu, dasawarsa, hari, } \\
\text { malam }\end{array}$ & $\begin{array}{l}\text { bertahun-tahun, berwindu- } \\
\text { windu, berakhir pekan }\end{array}$ \\
\hline 4. & Nama bahasa (NB) & $\begin{array}{l}\text { Inggris, Indonesia, Sunda, Bali, } \\
\text { Tetum }\end{array}$ & $\begin{array}{l}\text { mentetumkan, } \\
\text { menginggriskan }\end{array}$ \\
\hline 5. & $\begin{array}{l}\text { Ukuran dan takaran } \\
\text { (UK) }\end{array}$ & Pikul, goni, lusin, kodi & mengkodikan, berlusin-lusin \\
\hline 6. & Nama alat (NA) & gunting, sabit, cangkul, korden, & $\begin{array}{l}\text { mengguntingi, menyabit, } \\
\text { mencangkul, dikordeni }\end{array}$ \\
\hline 7. & Nama acara (NC) & wisuda, upacara, kenduri, misa, & $\begin{array}{l}\text { mewisuda, berupacara, } \\
\text { dimisakan }\end{array}$ \\
\hline 8. & $\begin{array}{l}\text { Nama konsep pikiran } \\
\text { (NP) }\end{array}$ & $\begin{array}{l}\text { agama, wahyu, teladan, nazar, } \\
\text { Tuhan }\end{array}$ & $\begin{array}{l}\text { beragama, mewahyukan, } \\
\text { meneladani, bernazar }\end{array}$ \\
\hline 9. & Tiruan bunyi (TB) & $\begin{array}{l}\text { embik, aum, gongong, deham, } \\
\text { desah, cicit, cekikik }\end{array}$ & $\begin{array}{l}\text { mencicit, mendeham, } \\
\text { mengaum }\end{array}$ \\
\hline 10. & Nama produk (NPr) & bakso, soto, teh, kopi & ngeteh, mbakso, nyoto \\
\hline 11. & $\begin{array}{l}\text { Nama benda berwujud } \\
(\mathrm{NBr})\end{array}$ & Kursi, meja, kemeja, & berkursi, bermeja, berkemeja \\
\hline
\end{tabular}

\section{SIMPULAN DAN SARAN}

\section{Simpulan}

Secara umum, verba denominatif (VDn) bahasa Indonesia (bI) cenderung mengisi fungsi predikat. Sebagai konstruksi derivatif, VDn terbentuk dari distribusi antara afiks-afiks derivasional dan berbagai tipe nomina. Afiks-afiks derivasional tersebut sekurang-kurangnya dapat berupa prefiks, konfiks, simulfiks, dan kombinasi afiks. Sementara itu, tipe-tipe nomina dapat berupa nomina dasar, nomina turunan, frasa nomina, nomina otentik, nomina ganda, nomina bernyawa, dan nomina tidak bernyawa. Secara khusus, distribusi antara afiksafiks derivasional dan tiap-tiap jenis nomina membentuk kaidah-kaidah linguistis sebagaimana disajikan pada bagian pembahasan. 


\section{Saran}

Berkaitan dengan penelitian konstruksi derivasional yang dapat mengisi fungsi predikat, berikut disajikan dua saran. Pertama, peneliti selanjutnya dapat membahas konstruksi verba derivasional yang diderivasikan dari adjektiva, adverbia, numeralia, atau kategori yang lain. Fokus penelitian tersebut layak diperhatikan untuk mendapatkan perbandingan ciri morfologis, sintaktis, dan semantis dari konstruksi verba derivasional yang diturunkan dari kategori selain nomina. Kelengkapan pembahasan tentang konstruksi verba derivasional dalam bI berguna untuk melengkapi pemerian teori tentang verba bI. Kedua, peneliti selanjutnya juga dapat melihat proses pembentukan konstruksi verba derivasional selain melalui afiksasi. Pada penelitian ini, afiksasi merupakan titik fokus penelitian yang utama dalam melihat konstruksi verba derivasional. Peneliti selanjutnya dapat mempertimbangkan adanya proses reduplikasi, transposisi, dan sebagainya. Fokus-fokus tersebut dapat melengkapi kekurangan-kekurangan dalam penelitian ini.

\section{DAFTAR RUJUKAN}

Acquaviva, Paolo 2014. The categories of Modern Irish verbal inflection. Journal of Linguistics, 50, pp 537-586 doi:10.1017/S0022226714000176. Diakses pada 20 September 2015, pukul 11.00 WIB.

Aikenvald, A.Y. dan Dixon, R.M.W. 2007. Serial Verb Constructions: A Cross Linguistic Typology. USA: Oxford University Press.

Akmajian, A., Demers, R.A., \& Harnish, R.M. 1979. Linguistics: An Introduction to Language and Communication. Cambridge: The MIT Press.

Booij G 2006, Inflection and Derivation. Dalam: Keith Brown, (Editor-in-Chief) Encyclopedia of Language \& Linguistics, Second Edition, volume 5, pp. 654-661. Oxford: Elsevier.

Bussmann, H. 1996. Routledge Dictionary of Language and Linguistics. New York: Rouledge.

Chaer, A. 2012. Linguistik Umum Edisi Revisi. Jakarta: Penerbit Rineka Cipta.

Chafe, W.L. 1970. Meaning and the Structure of Language. Chicago: Chicago University Press.

Crystal, D. 2008. A Dictionary of Linguistics and Phonetics Sixth Edition. Oxford: Blackwell Publishing.

de Guzman, V.P.D. 1978. "Syntactic Derivation of Tagalog Verbs". Oceanic Linguistics Special Publications, dalam JSTOR, http://www.jstor.org/stable/20006688. Diakses pada 19 September 2015, Pukul 08.00 WIB.

Dixon, R.M.W. 2008. 'Deriving Verbs in English". Language Sciences, 30:31-52.

Dixon, R.M.W. 2010. Basic Linguistic Theory: Grammatikal Topics. New York: Oxford University Press.

Dixon, R.M.W. dan Aikenvald, A.Y. 2002. Word: A Cross-Linguistic Typology. Cambridge: Cambridge University Press.

Dreyfuss, J.V. 1978. "Men-, Di-, and Ber-: Three Analyses". NUSA: Linguistic Studies of Indonesian and Other Languages in Indonesia 6: 1-6.

Folli, Raffaela dan Heidi Harley 2013. The syntax of argument structure: Evidence from Italian complex predicates. Journal of Linguistics, 49, pp 93-125 doi:10.1017/S0022226712000072. Diakses pada 19 September 2015, Pukul 09.00 WIB 
im Walde, Sabine Schulte. 2004. Automatic Induction of Semantic Classes for German Verbs. Computational Linguistics. Saarbrücken: Saarland University.

Kaswanti-Purwo, B. 1989. "Tata Bahasa Kasus dan Ketransitivan Verba" dalam B. Kaswanti-Purwo (ed), PELLBA 2: Pertemuan Linguistik Lembaga Bahasa Atma Jaya Kedua. Yogyakarta: Penerbit Kanisius.

Katamba, F. 1993. Morphology. New York: St. Martin's Press Inc.

Kilgarriff, A. 2008. "Google The Verb". Language Research and Evaluation, Vol. 44, No. 3, dalam Springer, http:// www.jstor.org/stable/40666362, Diakses pada 19 September 2015, Pukul 08.15 WIB.

Kridalaksana, H. 2009. Kamus Linguistik Edisi Keempat. Jakarta: Gramedia.

McCune, K.M. 1985. The Internal Structure of Indonesian Roots Part II. Jakarta: Badan Penyelenggara Seri NUSA, UNIKA Indonesia Atma Jaya.

Mangunwijaya, Y.B. 1999. Pohon-pohon Sesawi. Jakarta: KPG.

Moravcsik, E.A. 2013. Introducing Language Typology. Cambridge: Cambridge University Press.

Nanyang Technological University Multilingual Corpus (NTUMC). 2015. http://compling.hss.ntu.edu.sg/ntumc/. Diakses pada 19 September 2015, Pukul 08.15 WIB.

Parker, F. \& Riley, K. 2014. Linguistics for Non-linguists 5th Edition. Singapore: Pearson Education.

Poedjosoedarmo, S. 2001. Teori Tatabahasa Universal. Yogyakarta: FIB Universitas Gadjah Mada.

Ramlan, M. 1978. Kata Verbal dan Proses Verbalisasi dalam Bahasa Indonesia. Yogyakarta: Universitas Gadjah Mada.

Rose, J.H. 1969. "Relational Variation and Limited Productivity in Some Indonesian and English Verbal Derivation". dalam Springer, http:// www.jstor.org. Diakses pada 19 September 2015, Pukul 07.15 WIB.

Rose, J.H. 1973. "Principled Limitations on Productivity in Denominatif Verbs". Foundation of Language, Vol. 10, No. 4, dalam Springer, http:// www.jstor.org/stable/25000737. Diakses pada 19 September 2015, Pukul 08.15 WIB.

Rose, J.H. 1977a. "Principled Limitations on Productivity in Denominatif Verbs". NUSA: Linguistic Studies of Indonesian and Other Languages in Indonesia 3: 44-51.

Rose, J.H. 1977b. "Invention and Innovation in Denominatif Verbs". NUSA: Linguistic Studies of Indonesian and Other Languages in Indonesia 3: 52-55.

Sneddon, J.N., Adelaar, A., Djenar, D.N., \& Ewing, M.C. 1996. Indonesian: A Comprehensive Grammar 2nd Edition. London: Routledge.

Sudaryanto. 1983. "Keselarasan Pola-Urutan dalam Bahasa Indonesia". Disertasi. Yogyakarta: Universitas Gadjah Mada.

Suhandano. 1990. Kesesuaian Semantis Verba dan Objek dalam Bahasa Indonesia. Yogyakarta: Universitas Gadjah Mada.

Suhandano. 1991. Verba dan Perilakunya dalam Bahasa Indonesia. Yogyakarta: Universitas Gadjah Mada.

Suhandano. 2002. "Konstruksi Objek Ganda dalam Bahasa Indonesia", Humaniora, Vol. XIV, No. 1.

Sumarmo, M. 1977. "Syntactic and Semantic Well-formedness". NUSA: Linguistic Studies of Indonesian and Other Languages in Indonesia 3: 19-26. 
Verhaar, J.V.M. 1978. "Some Notes on The Verbal Passive in Indonesian". NUSA: Linguistic Studies of Indonesian and Other Languages in Indonesia 6: 11-19.

Verhaar, J.V.M. 1984a. "Affixation in Contemporary Indonesian" . NUSA: Linguistic Studies of Indonesian and Other Languages in Indonesia 18: 1-26.

Verhaar, J.V.M. 1984b. "The Categorial System in Contemporary Indonesian: Verbs". NUSA: Linguistic Studies of Indonesian and Other Languages in Indonesia 18: 27-64.

Verhaar, J.V.M. 1988a. "Phrase Syntax in Contemporary Indonesian: Noun Phrases". NUSA: Linguistic Studies of Indonesian and Other Languages in Indonesia 30: 1-46.

Verhaar, J.V.M. 1988b. "Phrase Syntax in Contemporary Indonesian: Nonnominal Phrases". NUSA: Linguistic Studies of Indonesian and Other Languages in Indonesia 30: 47-64.

Verhaar, J.V.M.1996. Asas-asas Linguistik Umum. Yogyakarta: Gadjah Mada University Press.

Wijana, I.D.P. 1991a. Inversion in Bahasa Indonesia. Yogyakarta: Faculty of Letters, Gadjah Mada University.

Wijana, I.D.P. 1991b. Frasa Nomina Beratribut Nomina. Yogyakarta: Perpustakaan Fakultas Sastra Universitas Gadjah Mada.

Wijana, I.D.P. 2010. Pengantar Semantik Bahasa Indonesia. Yogyakarta: Prodi S2 Linguistik dan Pustaka Pelajar.

Wijana, I.D.P. 2016 Metode Linguistik: Identifikasi Satuan-satuan Lingual. Yogyakarta: A.Com Press. 